\title{
Bearded sakis in south-eastern Amazonia-back from the brink?
}

\author{
Stephen F. Ferrari, Claudio Emidio-Silva, M. Aparecida Lopes and Urbano L. Bobadilla
}

\begin{abstract}
The endemic bearded sakis Chiropotes satanas satanas and Chiropotes satanas utahicki of south-eastern Amazonia are among the most threatened of this region's primates because of a combination of deforestation and hunting, and their apparent intolerance of habitat disturbance. Recent surveys at eight sites confirm that sakis are locally extinct in some areas where intense habitat fragmentation is exacerbated by hunting pressure, but also show that, in the absence of hunting, they can be relatively abundant in isolated forest fragments. Density was unexpectedly low in one protected area, however, which implies that caution is
\end{abstract}

\section{Introduction}

Bearded sakis Chiropotes spp. are medium-sized Amazonian primates specialized morphologically for seed predation (Kinzey \& Norconk, 1993). Hershkovitz (1985) recognized four taxa, two of which (Chiropotes albinasus and Chiropotes satanas chiropotes) are widely distributed in northern and central-southern Amazonia, respectively (Fig. 1). The two remaining taxa (Chiropotes satanas satanas and Chiropotes satanas utahicki) not only have more restricted geographic ranges, in south-eastern Amazonia, but are also endemic to the most densely populated and extensively deforested region of this biome.

Johns \& Ayres (1987) proposed that the southern bearded saki C. s. satanas was already 'beyond the brink' in eastern Amazonia as a result of a combination of factors. These included its intolerance of habitat disturbance and dependence on key resources, which include tree species valued for their timber, in addition

Stephen F. Ferrari (corresponding author) Department of Genetics, Universidade Federal do Pará, Caixa Postal 8607, 66.075-900 Belém-PA, Brazil. E-mail: ferrari@ufpa.br

Claudio Emidio-Silva Programa Parakanã, Convênio Eletronorte/FUNAI, 68.456-120 Tucuruí-PA, Brazil, and Biological Sciences Centre, Universidade Federal do Pará, Belém-PA, Brazil.

M. Aparecida Lopes Department of Biology, Universidade Federal do Pará, 66.075-900 Belém-PA, Brazil, and Department of Biology, University of Miami, USA.

Urbano L. Bobadilla Department of Experimental Psychology, Universidade Federal do Pará, 66.075-900 Belém-PA, Brazil.

Received 3 November 1998. Accepted 13 May 1999 necessary for the planning of long-term conservation strategies. Well-protected forest fragments of reasonable size ( $>5000 \mathrm{ha}$ ) appear to have good potential for the protection of bearded saki populations. While many of the region's major landowners may thus make a significant contribution to the management of saki populations, land conflicts are a potentially serious problem for the long-term conservation of not just these primates, but the region's fauna and flora as a whole.

Keywords Bearded saki, Chiropotes, deforestation, population density, south-eastern Amazonia. to deforestation and hunting pressure. The same factors also apply to the closely-related C. s. utahicki, although its geographic range is less densely populated, and deforestation is still relatively limited in comparison with that of C. s. satanas. For this reason, C. s. utahicki has been classified as Vulnerable to extinction, whereas C. s. satanas is one of the six Endangered primate taxa found in lowland Amazonia (Rylands et al., 1996).

Research carried out in the region over the past few years provides a slightly less alarmist view of both the current status and future prospects of these unusual monkeys, although it has also revealed unexpected problems. Perhaps surprisingly, one of the findings is that major landowners (latifundiários) may have a potentially important role to play in the long-term conservation of bearded sakis-and many other mammals - in south-eastern Amazonia.

\section{Methods}

Despite their current taxonomic distinction, the two bearded sakis considered here are similar enough morphologically to have been included in the same subspecies-C. s. satanas-prior to Hershkovitz's (1985) systematic revision. Because the few available data indicate that the two forms are also behaviourally and ecologically very similar, they are considered as a single metapopulation here, except where differences between subspecies are relevant.

Bearded saki populations were surveyed at eight sites in south-eastern Amazonia (Fig. 2). Sites 2, 6 and 8 are located within the geographic range of C. s. utahicki (the Xingu-Tocantins interfluvium), whereas the remaining sites lie within that of $C$. s. satanas. The latter 
taxon is distributed between the right bank of the Tocantins and the eastern limits of the Amazonian forest in the Brazilian state of Maranhão. Survey localities include isolated forest fragments of varying sizes, in addition to areas of virtually continuous forest (Table 1). Sites also varied considerably in the nature and degree of human activities, such as hunting, logging and habitat fragmentation, from negligible to intense. Human activities were evaluated qualitatively on the basis of both interviews with landowners and local residents, and general observations within each study area (presence of tree stumps, hides, etc.). Hunting pressure was also assessed through records of the number of shotgun shots heard during fieldwork, following Peres (1990).

Populations were surveyed between 1991 and 1997 using standard line transect methods (Brockelman \& Ali, 1986). At each site, a system of straight-line trails was cleared in a randomly chosen representative area of terra firma forest and marked at 50-m intervals with vinyl flagging. Trails were walked at an average speed of c. $1.5 \mathrm{~km} / \mathrm{h}$, primarily between 06.00 and 14.00 hours, with a total transect length of $101-533 \mathrm{~km}$ at a given site. Standard records collected at each sighting of bearded sakis included group size and composition (during a maximum of $10 \mathrm{~min}$ of monitoring), and perpendicular animal-trail distance, on which estimates of population density were based. Because the number of sightings was relatively small at all sites and perpendicular distances did not vary significantly (Bobadilla, 1998), the Kelker method was used to estimate densities using pooled data, given the problems associated with small sample size for calculations based on sighting functions (see Burnham et al., 1980). Data were also used to calculate sighting rates (sightings per $10 \mathrm{~km}$ of transect), mean group size (individuals per sighting) and the estimated total population at each site (population density $\times$ total area of forest).

\section{Results}

Bearded sakis were observed at all sites except the small forest fragment at the Fazenda Monte Verde (Table 2), where interviews with residents confirmed the local extinction of C. s. satanas. While hunting pressure is undoubtedly an important variable, habitat fragmentation may have been the decisive factor, given that the much larger-bodied red-handed howler monkey Alouatta belzebul is still found there (M. A. Lopes, unpublished data). The spatial requirements of bearded sakis are still poorly known, but the forest fragment at Monte Verde is smaller than the most reliable estimates of home range size for a single social group (Ayres, 1981; van Roosmalen et al., 1981). Monte Verde represents the largest remnant of the original forest cover in the Bragantine Zone, in the north-eastern extreme of the Brazilian state of Pará (see Johns \& Ayres, 1987; Vieira et al., 1996), so it seems reasonable to conclude that $C . s$. satanas is now effectively extinct from this region.

The exact influence of habitat fragmentation is unclear from the results from other sites, however (Table 2). In fact, the population density recorded in the next largest fragment, on the Fazenda Arataú (site 2), was
Fig. 1 Known geographic ranges of bearded sakis (cf. Hershkovitz [1985], Ferrari [1995], Norconk et al. [1996], Wallace et al. [1996] and Ferrari et al. [1999]). Ca, Chiropotes albinasus; Css, Chiropotes satanas satanus; Csc, Chiropotes satanas chiropotes; Csu, Chiropotes satanas utahicki.

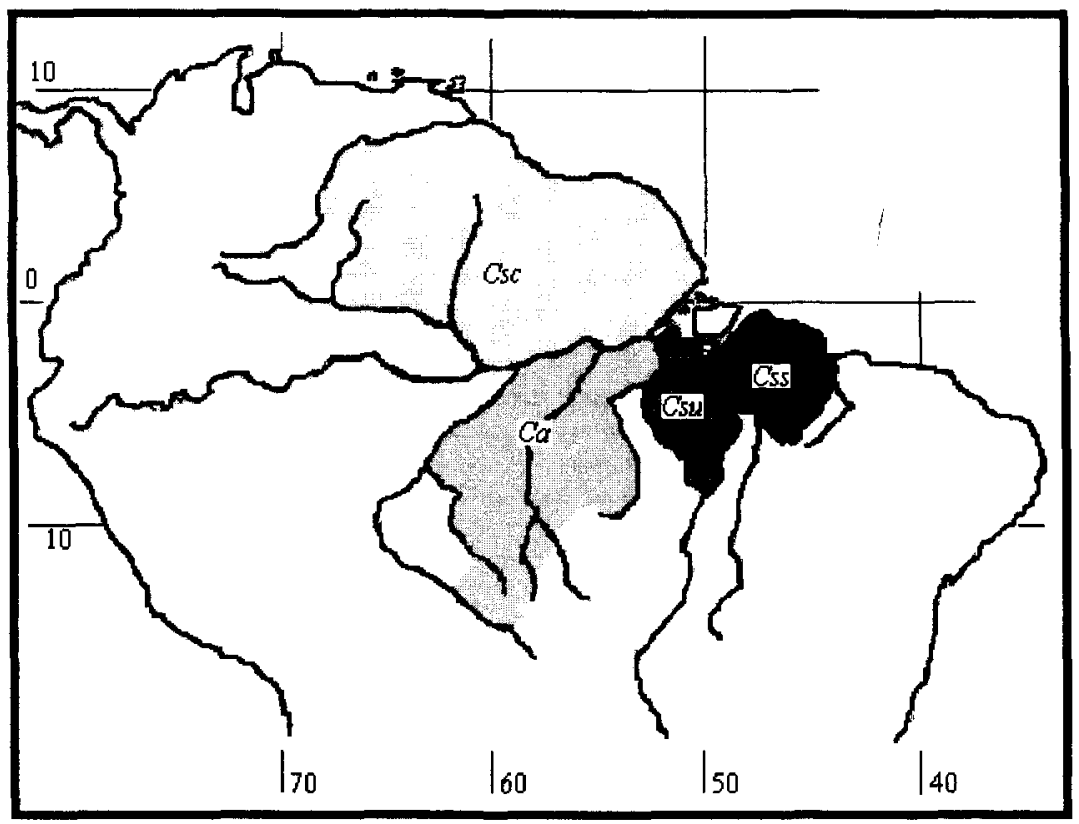




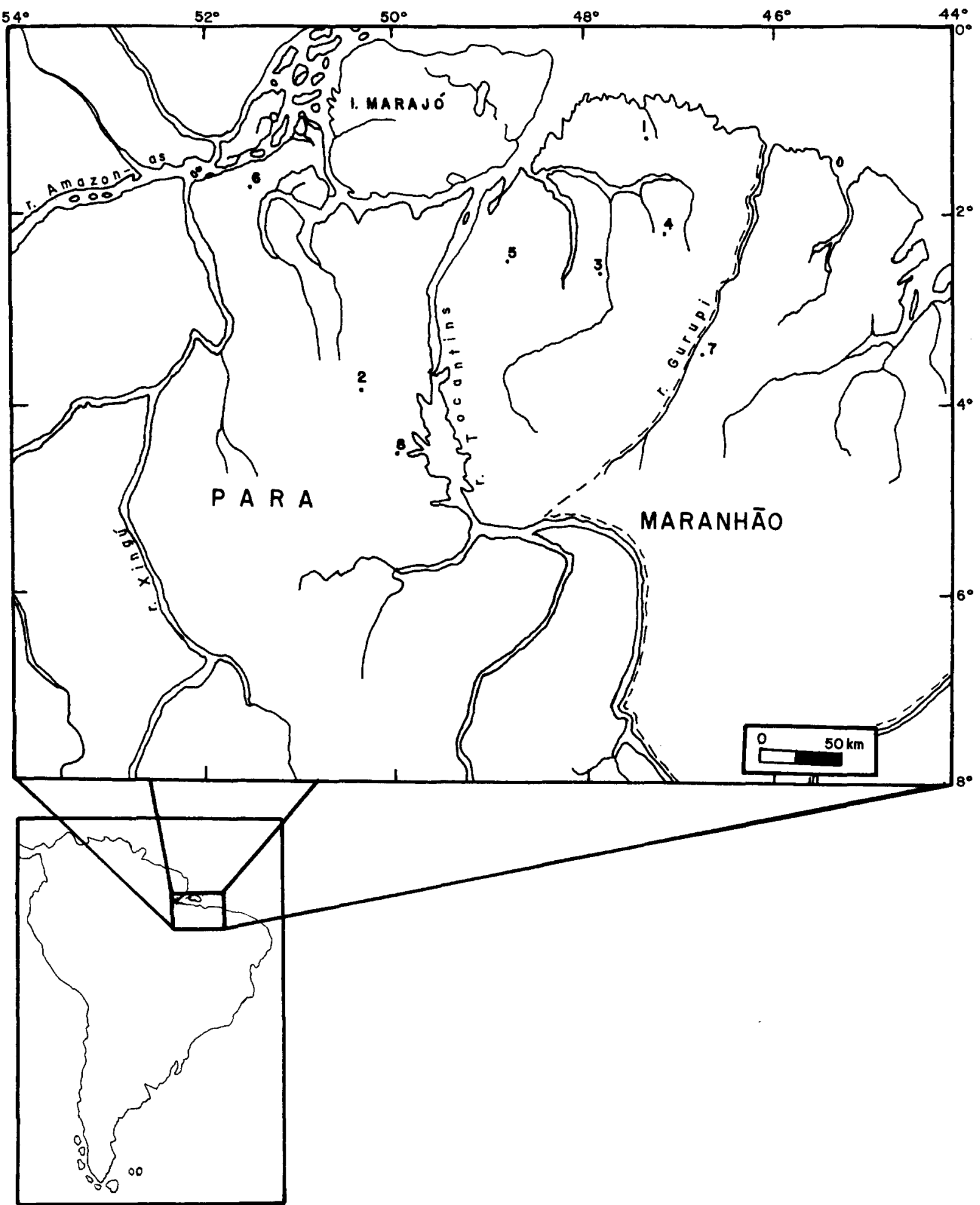

Fig. 2 Survey sites in south-eastern Brazilian Amazonia (see Table 1).

by far the highest ever recorded for Chiropotes, whereas densities recorded in large tracts of continuous forest (sites 6, 7 and 8) are largely indistinguishable from those of isolated fragments, with the exception of the Fazenda Badajós (site 3), where sakis were observed only once during $200 \mathrm{~km}$ of survey. While similar in 
size to Arataú, the forest fragment at Badajós is subject to considerably greater pressures in terms of both hunting and logging.

The abundance of sakis at the Fazenda Aratau is especially intriguing when compared with the much lower-but more 'normal' - density recorded at site 8 (Table 2), $50 \mathrm{~km}$ to the south-east (Fig. 2). The fragment at the former site has been isolated for more than 20 years, which contradicts the idea that the unusually high density of sakis might be due to a short-term concentration of fauna, especially as other primate species (including Saguinus midas, which usually benefits from habitat disturbance) were less abundant at Arataú than at most other sites. Bobadilla (1998) concluded that the high density of C. s. utahicki at this site was related to the use of alternative resources such as the mesocarp fruits of the babaçu palm Orbignya martiana, which is abundant there. Unfortunately, it is unclear whether the current high density reflects pre-existing levels and/or is related to habitat disturbance. Whatever the case, the evidence indicates that bearded sakis may be more tolerant of habitat disturbance than was previously assumed (Johns \& Ayres, 1987), although this tolerance may depend on specific local factors such as 'key' resources and, of course, hunting pressure.
By contrast, the second lowest sighting rate and density of bearded sakis were recorded at the ECFPn, an integral part of what is probably the most extensive, best-preserved and botanically diverse tract of continuous forest remaining in eastern Amazonia (Almeida et al., 1993; Lisboa, 1997). Population density would have been even lower but for the fact that relatively large groups of sakis were encountered at this site (Table 2). Once again, the factors determining these exceptional values are obscure (Bobadilla, 1998), but what is clear is that the adequacy of a protected area for the conservation of a given species is not necessarily guaranteed by its size or lack of disturbance. Clearly, then, the potential of any given site for the conservation of bearded sakis must be evaluated carefully within the context of overall management strategies.

Isolated fragments of forest on private land can obviously support only limited populations, but many of the region's latifundiarios are at least conscious of the value of conservation measures and, in contrast with the government agencies responsible for public reserves, are not only strongly motivated, but also have the means to protect their properties from encroachment. In addition, human population densities on cattle ranches are normally lower than those of equivalent areas colonized by smallholders, who also tend to rely

Table 1 Study sites in south-eastern Amazon

\begin{tabular}{|c|c|c|c|c|}
\hline Site & Area (ha) & Characteristics & Logging & Hunting pressure \\
\hline 1. Fazenda Monte Verde & 200 & Isolated & Moderate & High \\
\hline 2. Fazenda Arataút & 7500 & Isolated & Moderate & Low \\
\hline 3. Fazenda Badajós & 8000 & Semi-isolated & Intense & High \\
\hline 4. Fazenda São Marcos & 10,000 & Isolated & Moderate & Moderate \\
\hline 5. Real Agropecuária S.A. & 17,485 & Semi-isolated & None & High \\
\hline 6. Ferreira Penna Scientific Station (ECFPn) & 33,000 & $\begin{array}{l}\text { Part of 330,000-ha Caxiuanã National } \\
\text { Forest }\end{array}$ & None & None \\
\hline 7. Gurupi Biological Reserve & 341,000 & Part of a reserve complex of $1,000,000$ ha & Low & Low/moderate \\
\hline 8. Parakanã Territory & 351,697 & Contiguous with surrounding forest & None & None* \\
\hline
\end{tabular}

* Bearded sakis are not hunted by the Parakanã, although most other medium- and large-bodied mammals suffer intense hunting pressure.

Table 2 Sightings of bearded sakis and population densities at the different study sites

\begin{tabular}{|c|c|c|c|c|c|c|}
\hline Site & $\begin{array}{l}\text { Survey length } \\
(\mathrm{km})\end{array}$ & Sightings & $\begin{array}{l}\text { Sighting rate per } \\
10 \mathrm{~km}\end{array}$ & $\begin{array}{l}\text { Mean group size } \\
\text { (individuals) }\end{array}$ & $\begin{array}{l}\text { Population density } \\
\text { (individuals/sq } \mathrm{km} \text { ) }\end{array}$ & $\begin{array}{l}\text { Estimated total } \\
\text { population }\end{array}$ \\
\hline 1 & 202 & 0 & 0 & 0 & 0 & 0 \\
\hline 2 & 101 & 21 & 2.07 & 6.57 & 23.78 & 1784 \\
\hline 3 & 205 & 1 & 0.05 & 6.00 & 0.90 & 72 \\
\hline 4 & 408 & 14 & 0.34 & 7.00 & 6.44 & 644 \\
\hline 5 & 216 & 6 & 0.28 & 4.50 & 3.24 & 567 \\
\hline 6 & 533 & 6 & 0.11 & 9.16 & 2.88 & 951 \\
\hline 7 & 480 & 18 & 0.37 & 7.94 & 6.75 & 23,018 \\
\hline 8 & 178 & 6 & 0.34 & 6.20 & 5.81 & 20,434 \\
\hline
\end{tabular}


heavily on forests for subsistence resources, including game.

Nevertheless, land conflicts are a chronic problem in south-eastern Amazonia, and tensions have increased considerably in recent years, especially following the 1996 massacre of squatters by military police at Eldorado dos Carajás, located just south of site 8 . In addition to increasing pressure on remaining forests, either potentially or in practice, such conflicts also tend to have a negative influence, from a conservation viewpoint, on the attitudes of latifundiários. While supportive of conservation efforts, the owner of one of the ranches surveyed here, for example, plans to take what he sees as unavoidable measures to guarantee the integrity of his property, which will include logging part of the forest reserve. The manager of a second ranch became noticeably less co-operative with researchers immediately after the Carajás incident.

\section{Conservation perspectives}

In purely numerical terms, then, the existing metapopulations of C. s. satanas and C. s. utahicki appear to be relatively healthy, although habitat fragmentation and the consequent isolation of relatively small local populations is clearly a major long-term threat to both subspecies (Lande \& Barrowclough, 1987; Turner \& Corlett, 1996). A second positive aspect of the surveys was the finding that bearded sakis are apparently more tolerant of habitat disturbance than was assumed previously, contributing to the potential of habitat fragments for the eventual management of metapopulations.

Forest fragments of between 5000 and 20,000 ha, which are typical of the region's present-day landscape (outside the Bragantine Zone), thus seem able to sustain apparently healthy populations of more than 500 individuals, although the long-term viability of populations of this size is still debatable (Lande \& Barrowclough, 1987; Soulé, 1987; Thomas, 1990). Judging viability, and developing effective management strategies will nevertheless require far more detailed data than are currently available on relevant aspects of bearded saki biology, such as genetic variability, population dynamics and even feeding ecology. The evolution of the present-day landscape is also unpredictable, given that continuing fragmentation appears to be the norm, despite recent changes in federal legislation, which severely restrict clear-cutting of forest on Amazonian properties.

The answer to the initial question would thus seem to be that bearded sakis, in common with most other elements of the fauna and flora of eastern Amazonia, are on the brink of a potentially definitive decline fuelled primarily by widespread deforestation and habitat fragmentation. However, the situation is as yet far less critical than that of Brazil's Atlantic Forest, for example (Lopes \& Ferrari, 1993), although there is an urgent need for the development of adequate conservation policies. While private initiatives, rather than public entities, may play a key role in their implementation, the effectiveness of such policies will depend, ultimately, on the resolution of wider social problems such as the distribution of land and wealth.

\section{Acknowledgements}

Research on bearded sakis in eastern Amazonia has been supported by CAPES, CNPq, FNMA, WWFBrasil, WCI-New York, the Goeldi Museum, Grupo Queiroz Galvão, IBAMA and Programa Parakanã (Eletronorte-FUNAI). We would also like to thank Danilo Mendonça, Andréa Nunes, Antônio Sérgio Lima, Pedro Lisboa and all the many landowners in eastern Amazonia who supported the fieldwork.

\section{References}

Almeida, S.S., Lisboa, P.L.B. \& Silva, A.S.L. (1993) Diversidade florística de uma comunidade arbórea na Estação Científica Ferreira Penna, em Caxiuanã (Pará). Boletim do Museu Paraense Emílio Goeldi: Botânica, 9. 93-128.

Ayres, J.M. (1981) Observaçōes sobre a ecologia e o comportamento dos cuxiús (Chiropotes albinasus $e$ Chiropotes satanas, Cebidae: Primates). MSc dissertation, INPA/FUA, Manaus.

Bobadilla, U.L. (1998) Abundância, tamanho de agrupamento e uso do hábitat por cuxiús de Uta Hick Chiropotes satanas utahicki Hershkovitz, $1985 \mathrm{em}$ dois sítios na Amazônia oriental: implicaçōes para a conservação. MSc dissertation, Universidade Federal do Pará, Belém.

Brockelman, W.Y. \& Ali, R. (1986) Methods of surveying and sampling forest primate populations. In Primate Conservation in the Tropical Rain Forest (eds R. A. Mittermeier and R. W. Marsh), pp. 23-62. Alan Liss, New York.

Burnham, K.P., Anderson, D.R. \& Laake, J.L. (1980) Estimation of density from line transect sampling of biological populations. Wildlife Monographs, 72.

Ferrari, S.F. (1995) Observations on Chiropotes albinasus from the Rio dos Marmelos, Amazonas, Brazil. Primates, 36, 289-293.

Ferrari, S.F., Iwanaga, S., Coutinho, P.E.G., Messias, M.R., Cruz Neto, E.H., Ramos, E.M. \& Ramos, P.C.S. (1999) Zoogeography of Chiropotes albinasus (Platyrrhini, Atelidae) in southwestern Amazonia. International Journal of Primatology, 20 (in press).

Hershkovitz, P. (1985) A preliminary taxonomic review of the south American bearded saki monkeys genus Chiropotes (Cebidae, Platyrrhini), with the description of a new subspecies. Fieldiana Zoology, 27.

Johns, A.D. \& Ayres, J.M. (1987) Southern bearded sakis beyond the brink. Oryx, 21, 164-167. 
Kinzey, W.G. \& Norconk, M.A. (1993) Physical and chemical properties of fruit and seeds eaten by Pithecia and Chiropotes in Surinam and Venezuela. International Journal of Primatology, 14, 207-227.

Lande, R. \& Barrowclough, G.F. (1987) Effective population size, genetic variation, and their use in population management. In Viable Populations for Conservation (ed. M. E. Soulé), pp. 87-124. Cambridge University Press, Cambridge.

Lisboa, P. (1997) Caxiuanã. MCT/CNPq/MPEG, Belém.

Lopes, M.A. \& Ferrari, S.F. (1993) Primate conservation in eastern Brazilian Amazonia. Neotropical Primates, 1, 8-9.

Norconk, M.A., Sussman, R.W. \& Phillips-Conroy, J. (1996) Primates of Guyanan shield forests. Venezuela and the Guianas. In Adaptive Radiations of Neotropical Primates (eds M. A. Norconk, A. L. Rosenberger and P. A. Garber), pp. 69-83. Plenum Press, New York.

Peres, C.A. (1990) Effects of hunting on western Amazonian primate communities. Biological Conservation, 54, 47-59.

van Roosmalen, M.G.M., Mittermeier, R.A. \& Milton, K. (1981) The bearded saki, genus Chiropotes. In Ecology and Behavior of Neotropical Primates, vol. 1 (eds A. F. Coimbra-Filho and R. A. Mittermeier), pp. 419-441. Academia Brasileira de Ciências, Rio de Janeiro.

Rylands, A.B., Mittermeier, R.A. \& Luna, E.R. (1996) A species list for the New World primates (Platyrrhini): distribution by country, endemism, and conservation status according to the Mace-Land system. Neotropical Primates, 3, 113-160.

Soulé, M.E. (1987) Where do we go from here? In Viable Populations for Conservation (ed. M. E. Soulé), pp. 175-183. Cambridge University Press, Cambridge.

Thomas, C.D. (1990) What do real population dynamics tell us about minimum viable population sizes? Conservation Biology, 4, 324-327.

Turner, I.M. \& Corlett, R.T. (1996) The conservation value of small, isolated fragments of lowland tropical rain forest. Trends in Ecology and Evolution, 11, 330-333.

Vieira, I.C.G., Salomão, R.P., Rosa, N.A., Nepstad, D.C. \& Roma, J.C. (1996) O renascimento da floresta no rastro da agricultura. Ciência Hoje, 20, 38-44.

Wallace, R.B., Painter, R.L.E., Taber, A.B. \& Ayres, J.M. (1996) Notes on a distributional river boundary and southern range extension for two species of Amazonian primates. Neotropical Primates, 4, 149-151.

\section{Biographical sketches}

Steve Ferrari's principal research interests are the ecology and conservation of Amazonian primates. He has supervised a number of local postgraduates, including the masters' dissertations of the three co-authors.

Claudio Emidio-Silva is continuing his research on the effects of hunting and the development of wildlife management strategies in the Parakanã reservation, which will form the basis of his doctoral thesis.

Cida Lopes is a doctoral student at the University of Miami, and is currently investigating the effects of the local extinction of southern bearded sakis on seed dispersal patterns and the population dynamics of lecythid tree species.

Urbano Bobadilla has recently taken up a lecturing position at the Brazilian Lutheran University in his hometown of Porto Alegre, but plans to continue research on primate ecology, in particular population viability studies, in the near future. 